\title{
En kinesisk jernbane til Arktis? Historien om Belkomur - så langt
}

\author{
Arild Moe \\ Fridtjof Nansens Institutt, Norge
}

\begin{abstract}
A Chinese Railway to the Arctic? The Story of Belkomur - so Far
The further development of the Northern Sea Route, including the associated logistical chains and infrastructure, enjoys high priority in Russia, and inadequate south-north transportation capacity is recognized as a problem. China has shown increasing interest in Arctic shipping over the past ten years. The construction of a railway from the Urals, with connections to China, to a deep-water port with access to the Arctic Ocean appeared attractive, both as a strategic opportunity for China and as a natural area for Chinese engagement in Russia, given announcements of the close partnership and common interests between the two countries. Since 2012 various Chinese companies have shown interest in investing, and the conclusion of a concession agreement has been announced several times. The Russian federal authorities have voiced support, without committing budget funding. Increasingly, however, critical remarks have been heard from the federal government, although regional support remains strong. As of mid-2021 no firm agreement had been signed, and the project was put on hold. Reviewing the history of the project since Chinese companies were first engaged, this article offers insights on Russian regional authorities' scope for manoeuvre and the relationship between central and regional power. It also reveals Russian misinterpretations of Chinese interest in the project.
\end{abstract}

Keywords: Russia, China, railway, Arctic, port, infrastructure

\section{Innledning}

Utvikling av den arktiske sone står høyt på den politiske dagsorden i Russland. Og blant prioriteringene i nord er Den nordlige sjørute helt sentral (Moe, 2020). Det omfatter ikke bare drift og infrastruktur knyttet direkte til skipsfarten, men også forbindelsene mellom sjøruten og sydligere deler av landet som er industrielt utviklet og hvor det også er store naturressurser. Forbindelsene mellom de indre deler av landet og ishavskysten har tradisjonelt vært besørget av de store elvene. Jernbane- og veisystemet nord-syd er meget spinkelt. For å gi tilgang til sjøtransport i nord og lage en forbindelse til den transsibirske jernbane som går øst-vest gjennom de sydligere

Kontaktinformasjon: Arild Moe, e-post: arild.moe@fni.no 
delene av Sibir er det derfor foreslått flere nye jernbaneprosjekter. Felles for prosjektene er at de er meget kapitalkrevende.

Utbygging av nord-sydforbindelsene er relevant ikke bare $\mathrm{i}$ en intern russisk kontekst. Transport gjennom Russland på jernbane og bruk av Den nordlige sjørute er også viktig for internasjonal varetransport. Blant brukerne står Kina i en særstilling som verdens største handelsnasjon, grensende til Russland og med behov for adgang til markeder utenfor Russland, gjennom Russland. Det er derfor ikke så merkelig at mange har koblet planer om jernbaneutbygging med kinesiske interesser. Vi har sett et eksempel på dette i Norden, der planer om en jernbane mellom Kirkenes og Rovaniemi er blitt presentert som en mulig løsning på raskere adgang til europeiske markeder for kinesiske varer etter at de først er fraktet sjøveis på Den nordlige sjørute $(\mathrm{E} 24,2018) .^{1}$

Kinesisk engasjement i utviklingen av russisk Arktis har vært et tema i internasjonal forskning over flere år (f.eks. Conley, 2018; Hsiung \& Røseth, 2019; Koivurova \& Kopra, 2020). Alle peker på Kinas langsiktige interesser i regionen. I offisielle russisk-kinesiske erklæringer uttrykkes ønske om et bredt samarbeid i Arktis hvor utvikling og utnyttelse av Den nordlige sjørute fremheves (Felleserklæring, 2018). Omfattende kinesiske investeringer i LNG-prosjekter i det nordvestre Sibir betegnes som et uttrykk for den store kinesiske interessen i russisk Arktis (Hsiung, 2016). De politiske forbindelse mellom Moskva og Beijing er tettere enn noensinne, og på offisielt hold snakkes det om utvikling av et altomfattende samarbeid. Utviklingen av de økonomiske forbindelsene går imidlertid for langsomt, etter sentrale observatørers syn (Luzyanin \& Huasheng, 2020).

Det er blitt inngått formelle samarbeidsavtaler mellom Kina og Russland der jernbaneutbygging er blitt spesielt nevnt (Felleserklæring, 2015). Slike prosjekter kan også sees på som et ledd i kinesisk «infrastruktur-diplomati» - statlig engasjement i utbyggingen av en annen stats infrastruktur (Jia \& Bennett, 2018). Fra russisk side har det vært uttrykt store forventninger til kinesiske investeringer i infrastruktur som kan bidra til økonomisk utvikling i nord, men det finnes også russiske observatører som er skeptiske til kinesiske initiativer: Ligger det politiske ambisjoner bak Kinas ønske om sterkere innflytelse i Arktis (Gudev, 2019; Leonov, 2019)? Dette spørsmålet er også blitt stilt i Kina-kritiske vestlige rapporter som argumenterer for at Kina har en omfattende politikk for investeringer i arktisk infrastruktur generelt for å oppnå strategiske fordeler (Doshi et al., 2021).

I denne artikkelen skal vi se nærmere på et av de mest konkrete prosjektene som er blitt nevnt i denne sammenhengen, Belkomur (BELoe more-KOMi-URal)- utbyggingen av en jernbane mellom Kvitsjøen og Ural. Banen vil kunne gi industrisentrene

\footnotetext{
${ }^{1}$ Planen var at last fra Den nordlige sjørute skulle fraktes med tog fra Kirkenes via Rovaniemi og inn på det eksisterende finske jernbanenettet. Gods skulle gå videre sydover til sentrale deler av Europa via Baltikum og bygging av en jernbanetunnel mellom Finland og Estland var en komponent i logistikk-kjeden.
} 
i Ural direkte tilgang til utskipning og tilførsler via havnen i Arkhangelsk og vil kunne føre gods fra den transsibirske jernbanen frem til en havn i nord. Mange utenforstående sitter med inntrykk av at prosjektet er godt i gang og at kinesiske investorer med stor tyngde har engasjert seg. I 2017 rapporterte for eksempel det russiske nyhetsbyrået Tass at de første togene ville kunne rulle i 2023 (Tass, 2017).

Artikkelen viser hvordan prosjektet har utviklet seg og spesielt hvilken rolle kinesiske aktører har spilt.

- Hva er drivkreftene for gjennomføring av prosjektet?

- Hvem er aktørene på russisk og kinesisk side?

- Hva har motivert kineserne til å delta, og kan motivasjonen ses som et uttrykk for kinesiske statlige ambisjoner i Arktis?

- Hvilke problemer har oppstått i forhandlingene om prosjektet?

- Hvilke lærdommer kan trekkes?

Det er interessant å studere dette prosjektet også fordi historien forteller oss noe om handlingsrommet til regionale myndigheter i Russland så vel som det komplekse spillet mellom føderale myndigheter og regionene. Dessuten sier den noe om forskjeller i russisk og kinesisk forståelse av et prosjekt hvor det utenfra har sett ut som det er sterke felles interesser.

Prosjektet er gjennom årene blitt omtalt ikke så rent sjeldent av russiske føderale media, men den mer detaljerte rapporteringen om fremdriften finner man i regionale media som sammen med offisielle pressemeldinger og dokumenter, er hovedkildene i denne studien. Slike kilder gir imidlertid i liten grad et tilbakeblikk og inneholder ofte liten grad av analyse. De nøyer seg med å fortelle om dagens situasjon og se fremover. Historien må vi derfor i stor grad sette sammen selv. Et annet kjennetegn ved regionale media er at de ofte er positivt innstilt, i den forstand at de nærmest er forpliktet til å se på mulighetene en utbygging vil bety for regionen. Når vi bruker slike kilder har vi derfor liten grunn til å tro at situasjonen er bedre enn beskrevet. Fremstillingen er kun basert på russiske kilder. Utover enkelte offisielle uttalelser er materiale fra kinesisk side ikke brukt.

\section{Hva er Belkomur?}

Ideen om en jernbaneforbindelse mellom Ural og Kvitsjøen er mer enn hundre år gammel, men prosjektet ble først påbegynt i 1954 da $400 \mathrm{~km}$ ble bygget. Så stanset det, blant annet fordi tilgangen til tvangsarbeidere opphørte med oppløsningen av GULag-systemet (Belkomur, u.d.). På 1990-tallet var det flere som fattet ny interesse for prosjektet og de regionale myndighetene i Arkhangelsk, Komi og Perm etablerte i 1996 et felles regionalt utviklingsselskap, MK Belkomur. I dette selskapet fikk Komi 48,32 \%, Arkhangelsk 19,81\% og Perm 9,42\% av eierandelene. Mindre utbygginger fant sted rett etter etableringen av selskapet, men stoppet opp etter finanskrisen i 1998. 
Den planlagte jernbanen strekker seg fra Kvitsjøen (Arkhangelsk by) via Komi-republikken og dens administrasjonssenter Syktyvkar til Solikamsk i Perm kraj ved Ural. Derfra er det eksisterende forbindelse til den transsibirske jernbane. Prosjektet omfatter $1162 \mathrm{~km}$ jernbane, hvorav $712 \mathrm{~km}$ vil måtte bygges fra grunnen, mens resten er oppgradering av eksisterende strekninger bygget på femti-tallet.

Det har vært knyttet store forventninger til utbyggingen. Regionale myndigheter ser for seg omfattende næringsutvikling langs linjen og etablering av titusenvis av nye arbeidsplasser. Linjen vil gi adgang til skogressurser som hittil ikke har vært utnyttet. Videre vil Belkomur-jernbanen gi vesentlig bedre transportmuligheter for industrien i Ural. Den vil bedre mulighetene for utskipning av kunstgiødsel fra Perm, kull fra Komi og Kuzbass (Kemerovo) og stål fra Ural og Vologda (Belkomur, u.d.). De regionale drivkreftene virker derfor å være sterke.

I 2008 ble prosjektet inkludert i den offisielle russiske føderale Transportstrategien, så vel som i Jernbanestrategien. Til tross for positive signaler fra de føderale myndighetene ble det ikke avsatt midler til utbygging i føderale budsjetter. De regionale pådriverne for prosjektet utarbeidet derfor et opplegg for offentlig-privat finansiering, hvor tanken var at jernbaneutbyggingen skulle kombineres med investeringer i en rekke industriprosjekter i nærheten av traséen (Kuratova, 2011).

Det ble i 2012 beregnet at prosjektet ville koste omkring 176 milliarder rubler (tilsvarende ca 5,5 mill. USD etter daværende vekslingskurs). Det var forventet at banen kunne settes i drift allerede i 2018 og at den ville kunne transportere 30 millioner tonn med gods i året (Izotov, 2013). Prosjektet ble sett i sammenheng med, og ble betraktet som avhengig av, utviklingen av et annet stort infrastrukturprosjekt - en dypvannshavn i Arkhangelsk, beregnet i 2010 å koste 14 milliarder rubler (Tarakanov, 2014). Imidlertid var det per 2012 fortsatt ikke avsatt midler i føderale budsjetter, og industrielle investorer sto heller ikke i kø for å bidra til noen av prosjektene.

\section{Kina som deltager og investor}

De regionale myndighetene begynte derfor på dette tidspunkt å se seg om etter mulige utenlandske interessenter, og i november 2012 ble det undertegnet et memorandum om samarbeide mellom MK Belkomur og China Civil Engineering Construction Corporation (CCECC), et datterselskap av China Railway Construction Corporation (CRCC). I januar 2013 ble det etablert en arbeidsgruppe med representanter for de regionale myndighetene i Komi, Vnesjekonombank (den statlige russiske utviklingsbanken), det statlige russiske jernbaneselskapet $\mathrm{RZjD}$, det russiske transportministeriet, den statlige kinesiske utviklingsbanken og «en rekke kinesiske selskaper» (KomiOnline, 2015). Det virker ganske klart at interesser i infrastrukturutbygging var den viktigste drivkraften på kinesisk side. I februar 2013 annonserte CCECC at de var rede til å delta i prosjektet og ønsket å kjøpe en andel av aksjene i $\mathrm{MK}$ Belkomur i tillegg til å skaffe til veie langsiktige kinesiske lån til prosjektet (Tass, 2013). 


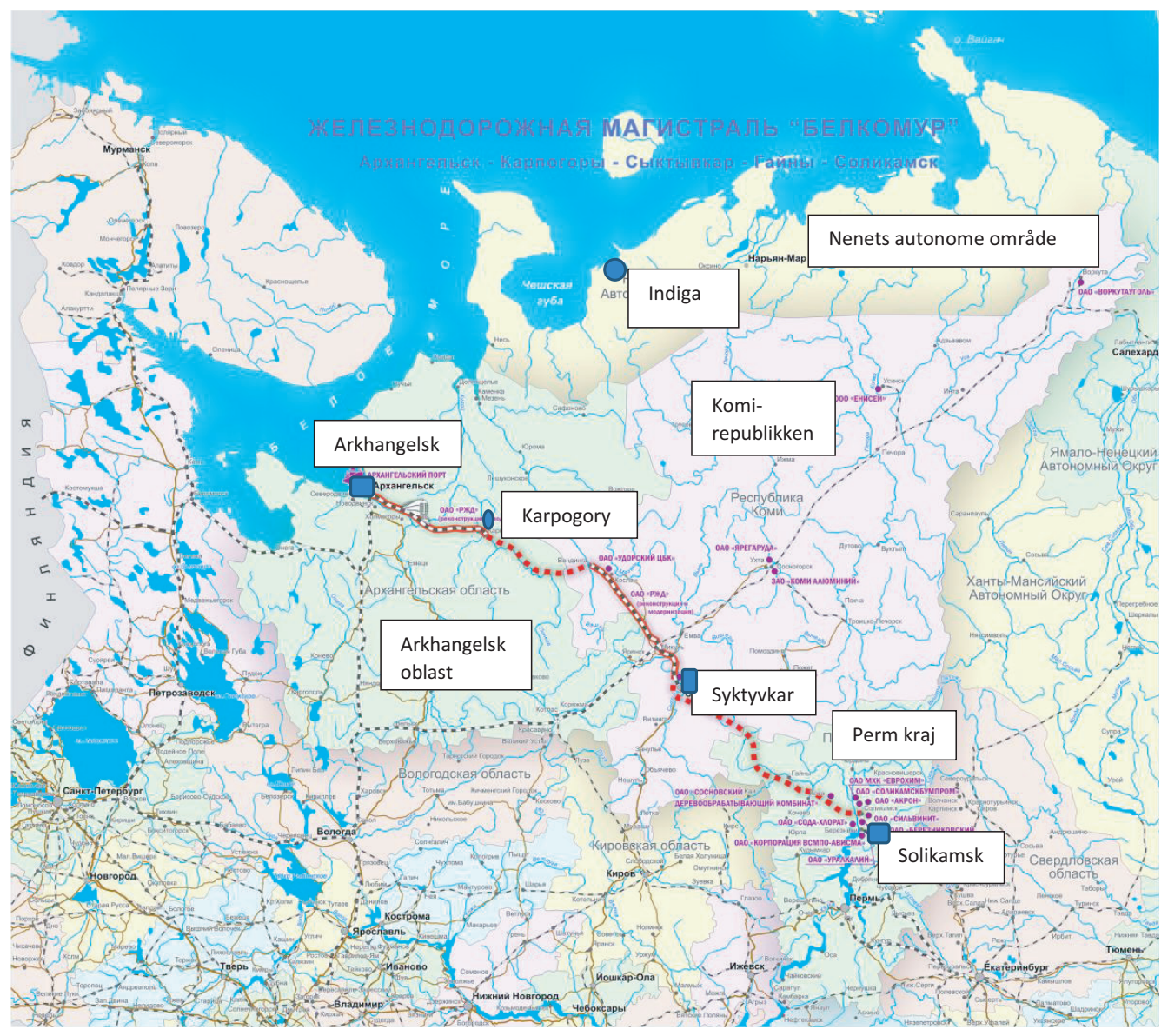

Belkomur-jernbanen. Rødstiplede strekninger er ikke bygget, på øvrige strekninger er det eksisterende linjer som må oppgraderes.

Kilde: www.belkomur.com

Potensialet for transitt-trafikk var nå kommet inn som et tilleggsargument for utbygging fra de russiske regionale pådriverne. Men det var ikke Kina som ble spesielt fremhevet i denne forbindelse, derimot Kasakhstan og Sentral-Asia, foruten gods fra Russlands egne østlige regioner (Autorisert representant, 2012).

Myndighetene i Arkhangelsk la i april 2013 frem planer for dypvannshavnen for kinesiske investeringsorganer. Både havnen og jernbanen var nå tatt inn i «Skjemaet for territoriell planlegging i den russiske føderasjon på området føderal transport $\rangle^{2}$ og i Den russiske transportstrategien til 2030. Første utbyggingstrinn av havnen var beregnet til å koste 36 milliarder rubler og ha en årlig kapasitet på 30 millioner tonn.

\footnotetext{
${ }^{2}$ Skhema territorialnogo planirovanija Rossijskoj Federatsii v oblasti federalnogo transporta.
} 
Det var forutsatt at havnen ville kunne ta imot skip på opp mot 100000 tonn dødvekt (DvinaInform, 2013).

Også selskaper fra Tyskland og Tyrkia viste interesse for jernbaneprosjektet, (KomiOnline, 2013). De falt fort fra, men kineserne var utholdende. Potensielle kinesiske investorer besøkte Komi i februar 2015, og to måneder senere var igjen en delegasjon fra Komi i Kina etter invitasjon fra China Railway Construction Bridge Engineering Bureau Group Co., Ltd. Det ble meldt om at samarbeidsprotokoll var under utarbeidelse med flere kinesiske selskaper, inkludert China Railway Construction Corporation, Ltd., China Poly Group og Poly Technologies, Inc. (KomiOnline, 2015). Sistnevnte har bredere interesser $\mathrm{i}$ handel og teknologi, deriblant våpen, og er nært knyttet til kinesiske myndigheter (China Poly Group, u.d.). Med rimelighet måtte deres inntreden kunne tolkes som et kinesisk ønske om et bredere engasjement rundt Belkomur og at deltagelsen hadde støtte på toppnivå.

Da president Putin besøkte Beijing i september samme år, ble saken behandlet i samtaler mellom ham og president $\mathrm{Xi}$ og en avtale om gjennomføring av prosjektet ble inngått mellom MK Belkomur og Poly Technologies Inc, i nærvær av Putin og representanter for de tre regionene Arkhangelsk, Perm og Komi. Ifølge lederen av Komi «bekreftet inngåelsen av avtalen om samarbeid i et internasjonalt format, innenfor rammen av forhandlinger mellom lederne for Russland og Kina, den utvilsomme viktigheten av prosjektet for våre land»(Komiinform, 2015). Det er rimelig å anta at også kinesiske selskaper tolket Putins nærvær som en støtte til prosjektet.

Prosjektet ble også lagt frem på det andre russisk-kinesiske investeringsforumet EKSPO i Harbin i Kina i oktober 2015. Guvernøren i Arkhangelsk uttalte at «ifølge russiske og kinesiske eksperter er prosjektet i full overensstemmelse med strategien for 'Den nye silkeveien'». Drøftelser med kineserne omfattet også investeringer i oljeraffinering, papir og cellulose, metall, høyteknologi, maskinbygging og bearbeidende industri (Dvinanews, 2015).

Fra russisk side antok man at kineserne hadde sterke interesser i Belkomur: deltagelse $i$ jernbaneutbygging, investering i og utbygging av industri langs linjen og nye transittmuligheter for varer fra Kina. Men det virker som det var russerne selv som var mest opptatt av transittmulighetene, og den russiske handelsrepresentasjonen $\mathrm{i}$ Kina lovte å arbeide for å vekke ytterligere interesse for prosjektet blant kinesiske spedisjons- og transportselskaper (Dvinanews, 2016). Det kunne tyde på at det i utgangspunktet ikke var mange kinesiske selskaper som så transport via Belkomur som en interessant løsning for seg.

Uten tvil var forventningene store til en rask oppstart av prosjektet. På dette tidspunkt var utvikling av Russlands arktiske sone løftet høyt opp på den politiske dagsorden. De regionale myndighetene argumenterte for at prosjektet måtte sees som en integrert del av infrastrukturen i Russlands arktiske sone, sammen med havneutbygging i Sabetta på Jamal-halvøya og utvidelsen av havnen i Murmansk, som til sammen ville ha stor betydning for Den nordlige sjørute. I 2016 ble det foreslått å inkludere Belkomur i listen over strategiske prosjekter i det russisk-kinesiske 
samarbeidet og i det russiske statsprogrammet for sosial og økonomisk utvikling i Russlands arktiske sone. Visestatsminister Rogozin advarte likevel mot å ensidig satse på kinesiske investorer og etterlyste interesse fra tunge russiske industrielle aktører. «De [kineserne] vil komme til prosjektet når de forstår at vi selv [Russland] trenger det og at vi kan giennomføre det uten dem» (DvinaInform, 2016).

Rogozin, som leder av statskommisjonen for Arktis, fikk utarbeidet en finansiell plan for prosjektet som ble oversendt til regjeringen. Tanken var at jernbaneprosjektet skulle giennomføres som en konsesjonsavtale (Dvina29, 2016). Innholdet i avtalen ble allerede skissert. Det kinesiske selskapet skulle betale 5,5 milliarder dollar (343 milliarder rubler) og drive linjen som en konsesjon. I løpet av 21 år skulle så kineserne årlig få utbetalt 10,8 milliarder rubler, hvoretter linjen ville bli russisk eiendom. Det var ventet at konsesjonsavtalen kunne undertegnes i februar-mars 2017 (KomiOnline, 2016). Samtidig ble det annonsert at kinesiske investorer var rede til å finansiere bygging av en dypvannshavn i Arkhangelsk (Tsygankova, 2016). Det ble også kunngjort at det kinesiske selskapet Poly International vurderte å bli storaksjonær i kullterminalen Lavna i Murmansk (Vedenejeva \& Dzjumajlo, 2017). ${ }^{3}$

En kinesisk delegasjon på mer enn 70 medlemmer med visestatsminister Wang Yang i spissen ankom Arkhangelsk i mars 2017 for å være til stede på den høyt profilerte konferansen "Arktis - dialogens territorium». Besøket ble kombinert med et møte i den russisk-kinesiske samarbeidskommisjonen hvor Belkomur og dypvannshavnen skulle være et tema (Nilsen, 2017). Under sitt plenumsforedrag på konferansen understreket president Putin Russlands interesse i utenlandsk deltagelse i utviklingen av Arktis, med henvisning til kinesiske partneres hensikt om å være med på å bygge jernbaner til nye dypvannshavner (Prezident Rossii, 2017a). Guvernøren i Arkhangelsk mente dette vitnet om politisk støtte til å gå videre med prosjektet (Pravda Severa, 2017a).

Men det ble ingen undertegnelse av avtaler. Dette ble ikke nærmere kommentert, men på russisk side gikk man videre med planene. 28 april gav statsminister Medvedev ordre om at det skulle iverksettes tiltak for å realisere prosjektet (Sjutsjalina et al., 2017).

Prosjektet fikk bred støtte under en spesialsesjon viet Arkhangelsk fylke i Føderasjonsrådet i Moskva i mai 2017 (Føderasjonsrådet, 2017). Formannen i Arktiskomitéen bemerket dog at spørsmål om landets strategiske sikkerhet i en situasjon der et kinesisk selskap får konsesjon i tredve år for drift av jernbanen «har sin plass. Selvfølgelig begynner folk å bli redde». Men han avviste at det var et reelt problem (Redkije zemli, 2017).

De regionale myndighetene tok sikte på å legge frem en finansieringsplan for regjeringen i oktober/november 2017. Enkelte detaljer om den nye planen kom ut

\footnotetext{
${ }^{3}$ Dette vakte stor oppmerksomhet i Murmansk, men etter kort tid ble det stille og ingen konkrete planer ble fremlagt. I 2020 så det ut til at hele prosjektet ville bli skrinlagt på grunn av endrede forutsetninger i kullmarkedet (Vedenejeva \& Zajnullin, 2020).
} 
i pressen. Den russiske staten var forutsatt å dekke 38 prosent av de samlede kostnadene på 251,5 milliarder rubler. Det russiske bidraget skulle betales løpende som et tilskudd til driften de første tyve år i perioden 2023-2043, mens Poly International skulle ta seg av alle investeringene. Banen skulle imidlertid drives av det russiske statlige jernbaneselskapet, noe som muligens kunne fortolkes som et krav om å begrense kinesisk direkte kontroll med banen. Etter at kinesisk side hadde fått igjen sin investering ville banen bli overdratt til RZjD - i 2052 (Pletnev, 2017). Regionale myndigheter forventet at banen ville frakte mineraler, kunstgjødsel, tømmer, cellulose, oljeprodukter og containere, og at 40 nye foretak med 45000 ansatte ville bli opprettet langs den (Pletnev, 2017).

I september 2017 instruerte president Putin regjeringen om å fremlegge forslag til realisering av Belkomur til diskusjon innen 1. januar 2018, med statsminister Medvedev som ansvarlig (Prezident Rossii, 2017b). I begynnelsen av september reiste på nytt en delegasjon fra Arkhangelsk fylke til Kina. De presenterte planene for Belkomur og dypvannshavnen i Arkhangelsk for kinesiske myndigheter (Transportministeriet og Handelsministeriet), den kinesiske Exim-banken, foruten investoren Poly Group og det store kinesiske shipping-selskapet Cosco. Den russiske rapporten fra møtene var meget optimistisk. Det het at de kinesiske myndighetsrepresentantene hadde tro på at en konsesjonsavtale kunne undertegnes før utløpet av året (Pravda Severa, 2017b). Myndighetene i Komi annonserte at de ville selge det meste av sin andel i MR Belkomur, til en utropspris av 540 mill. rubler tilsvarende ca. 8 mill. dollar, og at dette ville bringe «store spillere» inn i prosjektet (Babajeva, 2020). Det ble forstått at man ventet en kinesisk inntreden her.

\section{Kritikk og vakling}

Parallelt med de optimistiske uttalelsene hadde det fremkommet økende kritikk av de økonomiske forutsetningene for deler av prosjektet. Det later til at det særlig var det russiske jernbaneselskapet RZjD, som var forutsatt å være en partner, som førte an i kritikken, understøttet av sitt eget forskningsinstitutt. De hevdet at bare $1 / 3$ av det antatte fraktvolumet kunne betegnes som sikkert, og at mye av den forventede trafikken betinget at gods ble overført fra andre eksisterende strekninger, noe jernbaneselskapet ville tape betydelig på. Med disse forutsetningene er det ikke merkelig at selskapet vendte tommelen ned. De ba om at Belkomur ble lagt på is til etter 2025 og signaliserte at de hadde andre prioriteringer (Sjutsjalina et al., 2017).

Som nevnt hadde det lenge vært klart at utbygging av dypvannshavn i Arkhangelsk var en nødvendig forutsetning for økonomien i jernbaneprosjektet. Men nå het det at de aktuelle farvannene var for grunne og utsatt for sedimenter. Dessuten kunne isforholdene vanskeliggjøre trafikk i perioder. Enkelte regionale representanter begynte å skissere en alternativ jernbanelinje - via Komi til Indiga ved Barentshavet i Nenets autonome distrikt. Denne havnen ville ligge mye gunstigere til med tanke på 
Den nordlige sjørute, men manglet ellers alt annet - som infrastruktur og befolkning (Gorokhova \& Babajeva, 2017). Dessuten ville den ekskludere Arkhangelsk fylke fra prosjektet. (Riktignok er Nenets autonome område formelt en del av Arkhangelsk fylke, men samtidig er det et eget føderasjonssubjekt. Gjennom årene har det stadig vært politiske konflikter mellom fylkesadministrasjonen og myndighetene i Nenets.)

Ledelsen i Komi så ut til å satse på denne hesten da de mot slutten av 2017 besøkte Bahrain på jakt etter investorer til prosjektet, kalt Barentskomur (BARENTS, KOMi, URal), som klart ville være et alternativ til Belkomur og altså fullstendig omgå Arkhangelsk fylke. Dette ble av regionale media i Komi tolket som at forhandlingene med kineserne om Belkomur ikke gikk så godt (Morokhin, 2017).

Myndighetene i Komi utsatte tilbudsfristen for salget av andeler i Belkomurselskapet flere ganger, men ingen interessenter meldte seg og det ble heller ikke inngått noen konsesjonsavtale med kinesiske selskaper. I det hele tatt ble det ganske stille om prosjektet. To sentrale Kina-forskere i Moskva bemerket at «til tross for prinsippet om et altomfattende russisk-kinesisk partnerskap og strategisk samarbeide forblir som tidligere ambisiøse planer om bygging av Belkomur med kinesisk deltagelse urealisert» (Petrovskij \& Filippovna, 2018).

Det ble heller ikke rapportert noe om oppfølgning av Putins ordre til regjeringen, ut over en bemerkning fra transportministeren i februar 2018 om at han «var i ferd med, sammen med initiativtageren, å vurdere hensiktsmessigheten ved gjennomføring og strukturen til Belkomur-prosjektet» (Transportministeriet, 2018). I slutten av mai 2018 ble det imidlertid rapportert at det under St. Petersburg økonomiske forum var inngått en avtale med den Euroasiatiske utviklingsbanken om et syndikert lån på 278 milliarder rubler til prosjektet (Pravda Severa, 2018). Igjen ble det stille. Men i en felleserklæring fra presidentene Xi og Putin fra juni 2018 var transport-infrastruktur prosjekter i Arktis listet som et av mange områder der det var enighet om å samarbeide (Felleserklæring, 2018). Allikevel er det mulig at kinesiske interessenter nå hadde forstått at russiske føderale myndigheters støtte til Belkomur var svært betinget.

På den store Arktis-konferansen i St. Petersburg i april 2019 kom så en kalddusj fra visestatsminister Jurij Trutnev, som nå hadde fått ansvaret for Arktis. Han gav en meget negativ vurdering av Belkomur: «... jeg mener at startsignalet for gjennomføring av et hvilket som helst prosjekt bestemmes av avkastningen [...] men et entydig svar på om dette prosjektet er gunstig for landet er ennå ikke gitt» (Trunina \& Podobedova, 2019). Han sa han ville kunne skifte mening hvis det ble vitenskapelig bevist at prosjektet var rentabelt.

Mot slutten av 2019 ble Belkomur allikevel nevnt i regjeringens plan for utviklingen av infrastruktur for Den nordlige sjørute, men det het at prosjektet måtte re-kalkuleres, for så vidt det Trutnev hadde anbefalt (Pravda Severa, 2020a). Men i planen er Belkomur sidestilt med Barentskomur. Om begge heter det at reviderte planer skal foreligge i desember 2022 (Regjeringsordre, 2019). I regjeringens Strategi for utviklingen av den arktiske sone fra oktober 2020 står det bare at 
hensiktsmessigheten ved utbygging av banen skal substansieres (Prezident Rossii, 2020). Dermed kan det se ut som videre utvikling av prosjektet er frosset for en tid fremover.

Imidlertid var det kinesiske jernbaneinfrastrukturselskapet China Railway Construction Corporation (CRCC) nå kommet på banen igjen. I et møte i Moskva med Belkomur-selskapet i februar 2020 erklærte CRCC seg interessert i å delta som investor og kontraktør for utbyggingen av banen. En samarbeidsavtale skulle utarbeides etter at det kinesiske selskapet hadde fått adgang til alle konfidensielle opplysninger om finansielle og organisatoriske aspekter ved prosjektet (BNK, 2020). Pussig nok var det ingen henvisning til memorandumet om samarbeid mellom kinesernes datterselskap og MK Belkomur som var blitt inngått i 2012, og som er nevnt ovenfor (Belkomur, 2020). Per juli 2021 foreligger det ingen nye opplysninger om dette samarbeidet. Nettsiden til MK Belkomur er ikke oppdatert siden mars 2020, noe som kan tyde på at aktiviteten til selskapet er blitt kraftig redusert.

\section{Enda et konsept}

Det kunne dermed se ut som om ringen var sluttet hva angår kinesisk deltagelse. Imidlertid har historien om Belkomur flere fasetter.

Igor Orlov, guvernør i Arkhangelsk fylke, hadde vært en ivrig forkjemper for Belkomur og dypvannshavnen. I april 2020 trakk han seg imidlertid fra stillingen og ble erstattet av Alexander Tsybulskij, som inntil da hadde vært leder for Nenets autonome område - og en støttespiller for Barentskomur-prosjektet. Skiftet hadde store konsekvenser. Allerede i mai gikk Tsybulskij som fungerende guvernør ut mot planene om en dypvannshavn i Arkhangelsk by og erklærte at den var uhensiktsmessig fordi den aldri ville kunne ta imot de største båtene som brukes på Den nordlige sjørute. En havn i Indiga, som ligger i Nenets, ville derimot kunne spille en viktig rolle for sjøruten som den østligste isfrie havn i Barentshavet og uten dybdebegrensninger (Pravda Severa, 2020b). Han presenterte en visjon om store fraktmengder fra Sentral-Asia, 5 millioner tonn fra Kirgisistan og 30-40 millioner tonn kull fra Kasakhstan, i tillegg til gods fra Kina (Tass, 2020).

En slik omprioritering ville være meget sensitiv i vide kretser i Arkhangelsk fylke. Tsybulskij lanserte imidlertid en jernbaneløsning som også ville tilgodese Arkhangelsk. I den tidligere skissen for havnen i Indiga var det forutsett en jernbaneforbindelse fra Komi-Barentskomur. Nå argumenterte Tsybulskij for i stedet å bygge en avgrening fra Belkomur-traséen ved Karpogory $500 \mathrm{~km}$ nordover til Indiga. Slik kunne Indiga også brukes til utskipning av produkter fra Arkhangelsk, primært trevare, fremfor at slik last ble sendt ut via St. Petersburg (Pravda Severa, 2020b). Dermed forutsatte han at både Belkomur og dypvannshavnen i Indiga ble utbygget, men altså ikke dypvannshavnen i Arkhangelsk og Barentskomur. Dette kunne også sees som et smart politisk grep etter at en fullstendig sammenslåing av Arkhangelsk fylke og Nenets autonome område der Nenets ville ha mistet sin 
status som eget føderasjonssubjekt hadde mislykkes. Nå ville de to føderasjonssubjektene få interesser i et felles prosjekt (Glumskov, 2020). Tsybulskij fulgte opp med et møte med vise-transportministeren i august 2020 hvor han erklærte at man måtte gå videre med planene (Babajeva, 2020).

Dette grepet - å koble Belkomur med utbygging av Indiga - har ikke fått noen videre støtte fra føderalt hold. Private interesser fortsetter imidlertid å arbeide for utbyggingen av havnen i Indiga knyttet til et LNG-prosjekt i området og driver også lobbyvirksomhet for bygging av Barentskomur-banen (Vedenejeva, 2021). Finansiering foreligger ikke og kinesiske interessenter er ikke nevnt $\mathrm{i}$ denne forbindelse. Arkhangelsk fylke arbeider med planer for videreutvikling av havnen i Arkhangelsk og diversifisering av lastgrunnlaget, mens det er stille om utbygging av dypvannshavn der (Tass, 2021). Føderale myndigheter planlegger ingen investeringer i havnen i Arkhangelsk før tidligst 2023 (Rosmorport, u.d.).

\section{Hvilke lærdommer kan trekkes?}

Belkomur er ikke en avsluttet historie, men prosessen hittil gir grunnlag for flere refleksjoner. For det første kan det slås fast at prosjektet ikke har kommet i gang, til tross for et stort antall møter, løfter og erklæringer. Det at et prosjekt blir nevnt i russiske føderale planer og strategier (som det er mange av) trenger ikke bety noe. Man kan trygt si at positive erklæringer på høyt nivå både på russisk og kinesisk side heller ikke trenger å bety noen ting. Dette er ingen ny innsikt, men det er viktig stadig å bli minnet om det, ikke minst for utenlandske observatører. Ofte blir strategier og offisielle planer tatt for å være mer forpliktende enn de faktisk er.

Belkomur er et stort interregionalt prosjekt, men hovedaktørene og pådriverne for prosjektet har vært regionale myndigheter, særlig i Komi og i Arkhangelsk. I utgangspunktet var utbyggingen et rent russisk anliggende, hvor utløsning av det økonomiske potensialet i føderasjonssubjektene langs banen sto i sentrum. Kinesiske partnere kom inn som en mulig løsning på finansiering og teknisk gjennomføring av prosjektet, men det utvidet også begrunnelsen for prosjektet til i større grad også å omfatte transitt av gods.

Det er interessant å notere seg at de regionale myndighetene har kunnet operere nokså fritt og inngå diverse samarbeidsavtaler med kinesiske aktører. Avtalene som er inngått må kunne karakteriseres som intensjoner, men man skal merke seg at regionale aktivister kan opptre utenlands uten nødvendigvis å ha helhjertet føderal støtte. For så vidt samsvarer dette med Russlands formelle oppbygning som en føderasjon. I virkelighetens verden er landet temmelig sentralisert, men kanskje ikke så sentralisert som vi utenfra gjerne tror. Riktignok har russiske føderale myndigheter vært orientert om Belkomur-prosjektet og også til en viss grad deltatt som støttespillere, men på føderalt nivå har ikke støtten vært særlig sterk. Allikevel har de regionale representantene kunnet holde prosjektet såpass varmt at kinesiske partnere har betraktet gjennomføring som realistisk. Kineserne må opplagt ha 
hatt inntrykk av at et betydelig føderalt økonomisk bidrag var sannsynlig, også på grunnlag av erklæringer fra føderalt hold. Dog har alle erklæringer om statlig finansiering vært knyttet til finansieringspakker hvor andre, det vil si kineserne, ville ta en stor andel av kostnadene. I de siste par årene har imidlertid den føderale skepsisen blitt sterkere og mer eksplisitt. Det i seg selv kan ha fått kinesiske interessenter til å revurdere utsiktene. Belkomur er derfor også en historie om regional aktivisme og dens begrensninger.

Føderal skepsis mot prosjektet har altså vært til stede hele tiden. Hvorfor har så de føderale myndighetene ikke stoppet det? Det kan være flere forklaringer, men en mulig tolkning er at man ikke kan se bort fra en regional-politisk dimensjon. Prosjektet vil utvilsomt ha stor betydning for økonomisk utvikling $\mathrm{i}$ en stor region. Å åpent desavuere planene vil skape motstand. De regionale myndighetene har dessuten visst å knytte prosjektet opp mot den store Arktis-satsningen og all retorikken som omgir den. Det gjør det litt vanskelig å gå mot en slik komponent. Men det er også mulig at de føderale myndighetene har trodd at kinesiske interesser ville være så store at mye av finansieringsutfordringen kunne løses av Kina, eller at de av politiske grunner lenge ikke ville gå mot et prosjekt de antok kineserne var interessert i. Burde allikevel ikke slike «misforståelser» vært oppklart tidligere? Hva som er formidlet i de lukkede diskusjoner er ukjent for denne artikkelens forfatter, men alt som er gjengitt i den betydelige dekningen i media er kjennetegnet av lav presisjon og lite detaljer om de økonomiske forutsetningene for prosjektet. Det store, men mer abstrakte potensialet har derimot vært en gjenganger.

Hva kan det kinesiske aktørbildet si oss? En antagelse har vært at Belkomur har strategisk betydning for Kina, men aktørbildet har vært mer broket enn man skulle forvente om dette var en politisk viktig, strategisk satsning. Flere selskaper har vært involvert; noen med utbygging av jernbane som spesiale, andre med bredere industrielle interesser. Det virker ikke som noen koordinert kinesisk satsning. Interesse har blitt uttrykt gjennom flere år, men det har ikke skjedd noe konkret.

Uten innsyn i den fullstendige prosjektdokumentasjonen (som riktig nok sies å være mangelfull) og de konfidensielle delene av intensjonsavtalene som er inngått, ser det ut til at prosjektet hviler på usikre forutsetninger om fraktgrunnlaget. Det er også påfallende, som påpekt av daværende visestatsminister Rogozin i 2016, at tunge russiske industrielle aktører i Ural, som angivelig vil ha stor nytte av prosjektet, ikke er kommet på banen. I stedet henvises det mer abstrakt til det store fraktpotensialet. Faktisk innrømmet fungerende guvernør i Arkhangelsk i april 2020 at «prosjektet er svakt ut fra et fraktgrunnlag-synspunkt. Det kreves store investeringer, men det økonomiske utbyttet er utilstrekkelig». Likevel konkluderte han med at man må beskjeftige seg med prosjektet fordi «regionens adgang til Den nordlige sjørute og utviklingen av transport-kompetanse er viktig» (Regnum, 2020).

Fra russisk side forutsatte man fra starten av at kineserne skulle stå for brorparten av investeringen, men ikke drive banen. Det er mulig at dette ble for mye å svelge for kinesiske Poly Group som lenge var betraktet som den mest sannsynlige 
investoren i prosjektet. Det ser ut til at de trakk seg ut mot slutten av 2017, ikke lenge etter at ovenstående prinsipper ble offentliggjort.

Andre kinesiske infrastrukturselskaper har kommet inn siden, men størrelsen på og betingelsene for deres eventuelle rolle er ikke kjent. I et annet stort kinesisk jernbaneprosjekt i Russland - høyhastighetsbanen Kazan-Moskva - ser det ut til at uenighet om fordeling av risiko og kontroll var en av årsakene til at prosjektet stoppet opp (Jia \& Bennett, 2018), selv om kostnader var den formelle begrunnelsen på russisk side for å utsette det prosjektet på ubestemt tid (Zubarev, 2020).

I tillegg til jernbanebygging og investeringer i industri i Ural var det antatt at forbedrede transittmuligheter for gods i containere var en viktig økonomisk drivkraft for kinesisk deltagelse. Mye tyder på at dette potensialet er mer begrenset enn antatt. Slik transitt forutsetter bruk av den transsibirske jernbanen. Et argument for Belkomur har vært at den vil avlaste det overbelastede jernbanenettet i den vestlige delen av Russland, men også banen østover fra Ural er overbelastet og en økning av kapasiteten vil være en meget langsiktig og kostbar affære. Det er også usikkert hvor stor den kinesiske interessen for jernbanetransitt av containere gjennom Russland til Europa er sammenlignet med alternativene sjøtransport (som er billigere) eller jernbanelinjer lengre syd (som er raskere). Kina har satset stort på jernbanelinjer gjennom Sentral-Asia (Sazonov, 2020).

Også grunnlaget for transitt av kull fra Kasakhstan er meget usikkert. Det fraktes allerede store mengder russisk kull på russisk jernbane som skipes ut fra havner i Baltikum og Murmansk. Imidlertid er tariffen for denne transporten svært lav, egentlig subsidiert (Khuzainov \& Ozjereljeva, 2019). Dette har vært et tiltak for å støtte russisk kullindustri. Det er meget lite sannsynlig at russiske myndigheter vil tilstå kullprodusenter $\mathrm{i}$ andre land en tilsvarende rabatt.

Den aller siste utviklingen av prosjektet, hvor dypvannshavnen i Arkhangelsk oppgis til fordel for Indiga er isolert sett ikke negativ for kinesiske interesser. Adgang til en havn i nord har hele tiden vært en sentral motivasjon for dem, og Indiga har som havn en del fortrinn. Men utbygging av Indiga vil øke totalkostnadene betraktelig og sannsynligheten for gjennomføring blir derfor antagelig mindre. Samtidig gir en så grunnleggende omlegging av prosjektet inntrykk av dårlig grunnarbeid fra russisk side, der også det alternative Barentskomur-prosjektet trekker ned av samme årsak.

Sett fra kinesiske kommersielle aktørers side må investeringer i et prosjekt med så uklare forutsetninger fortone seg som svært risikable. Dette samsvarer med et av de generelle problemene $i$ samarbeidet om investeringer identifisert $i$ en russisk-kinesisk rapport (Ivanov, 2018). Som infrastruktur-diplomati betraktet har ikke Belkomur-prosjektet vært vellykket for kineserne, men de har så langt heller ikke tapt mye økonomisk. Balansen mellom kommersielle og statlige interesser i kinesiske selskapers utenlandsinvesteringer er meget omdiskutert og vanskelig å definere (Jones \& Zou, 2017). Ifølge lederen for Kinas kommisjon for administrasjon og kontroll av statlig eierskap, sitert av Wu (2018) skal «state firms become 'the most 
trustworthy' entities upon which the party and the country rely and an important force for China's ambitious trade and infrastructure strategy, known as the Belt and Road initiative». I tilfellet Belkomur ser det ikke ut til at kinesiske myndigheter har presset kinesiske selskaper til å gå videre eller at de har villet kompensere for den kommersielle usikkerheten.

Men hva med de strategiske interessene i Arktis mange tilskriver Kina? Kina har ikke grepet det som ser ut som en stor mulighet, og hvor de var invitert, til å etablere en korridor til Arktis. Kanskje ikke adgang til en slik korridor - som de ikke vil få full kontroll over - vurderes som så viktig av kinesiske myndigheter som mange tror? Og selv om en slik jernbaneforbindelse kan ha strategisk interesse, kommer man ikke forbi at et prosjekt i denne størrelsesorden må ha et solid økonomisk grunnlag, noe Belkomur tydeligvis ikke har. Det at kinesiske selskaper har investert tungt i russiske LNG-prosjekter i Arktis har liten relevans for satsning på jernbanen. Deltagelsen i Yamal LNG kan sies å ha gitt Kina et strategisk ankerfeste i Arktis, men investeringene der er også trygge for kinesiske selskaper ut fra et kommersielt perspektiv (Henderson \& Moe, 2019).

Denne studien har ikke hatt tilgang på kinesiske kilder, og kildene som er blitt brukt gir ikke innblikk i samtalene som har vært ført mellom kinesiske og russiske parter, ut over offisielle erklæringer og oppsummeringer. Det er uklart om det faktisk har funnet sted detaljerte forhandlinger eller om det kun har dreiet seg om innledende samtaler. Uansett virker det ikke som det er fastlåste forhandlinger som har stoppet kinesisk deltagelse. Det er mer sannsynlig at en kinesisk revurdering av de grunnleggende forutsetningene for prosjektet har funnet sted i løpet av den perioden de har vært i kontakt med den russiske siden. Denne revurderingen har gitt en negativ konklusjon for potensielle kinesiske interessenter.

Fortellingen om Belkomur og Kina inneholder en del detaljer om hvordan et angivelig lovende samarbeidsprosjekt er blitt håndtert både fra kinesisk og russisk side. De russiske føderale myndigheters støtte til prosjektet har vært halvhjertet, men de har også gitt det sin støtte i konteksten av russisk-kinesisk samarbeid. I ettertid virker det som den kinesiske interessen kun har vært økonomisk og ikke et uttrykk for statlige ambisjoner. Forventningene til kinesiske investeringer har vært meget høye på regionalt nivå i Russland og i det siste kan det spores en viss skuffelse i medieoppslag. Men ikke i noen av mediene som er gjennomgått i forbindelse med denne artikkelen har det fremkommet mistenksomhet om kinesiske hensikter og fremgangsmåte. Kritikken retter seg mot forhold i Russland og selve prosjektet.

Vil så eventuell kinesisk misnøye med russisk håndtering av et tilsynelatende havarert prosjekt ha bivirkninger for det bilaterale politiske forholdet? Det er lite sannsynlig. For det første har prosjektet aldri hatt høyeste prioritet eller status i samarbeidet og kontaktene har vært mellom kinesiske selskaper og russiske regionale representanter. Muligens kan noen av de kinesiske selskapene som har sett på prosjektet mene at den russiske siden har lovet mer enn den har kunnet holde, men 
sentrale kinesiske myndigheter har ikke mistet ansikt. For det andre hviler det bilaterale samarbeidet på mer grunnleggende fellesinteresser av politisk karakter. Det betyr ikke at alt er harmoni. Historien til Belkomur kan si noe om hvorfor det hittil ikke er blitt noe av omfattende kinesiske infrastrukturinvesteringer i Russland.

\section{Om artikkelen}

Arbeidet med artikkelen er finansiert av Forsvarsdepartementets tilskuddsordning til akademiske institusjoner og universitetsmiljø innen sikkerhets- og forsvarspolitisk forskning. Forfatteren takker for konstruktive kommentarer og forslag fra redaksjonen, to anonyme fagfeller og Andrey Krivorotov.

\section{Referanser}

Autorisert representant. (2012, 9. oktober). Zjeleznodorozjnaja magistral «Belkomur» mozjet natsjat rabotu v 2018 godu [Jernbanelinjen Belkomur kan settes i drift i 2018]. Offisiell nettside for den autoriserte representanten til presidenten i Den russiske føderasjon i Volga føderale distrikt. Hentet 27. juli 2021 fra http://pfo.gov.ru/press/events/57977/

Babajeva, V. (2020, 9. august) Doroga na trillion: novaja zjizn «Belkomura» [Bane til en trillion: Nytt liv for Belkomur]. GoArctic. https://zen.yandex.ru/media/id/5dc69465c7891f51f5fb5143/doroga-na-trillionnovaia-jizn-belkomura-5f2f7d7b5f6783517f3408d0?utm_source=serp

Belkomur. (u.d.). Beloe more - Komi - Ural. Belkomur. Hentet 27. juli 2021 fra http://www.belkomur.com/ belkomur/1.php

Belkomur. (2020, 2. mars). Pressemelding fra MK Belkomur. http://www.belkomur.com/news/index.php? ELEMENT_ID $=2993$

BNK. (2020, 3. mars). Jesjtsje odna kitajskaja kompanija projavila interes k "Belkomuru» [Enda et kinesisk selskap har vist interesse for Belkomur]. https://www.bnkomi.ru/data/news/107930/

China Poly Group Corporation Ltd. (u.d.). Group Profile. Hentet 27. juli 2021 fra https:/www.poly.com.cn/ english/1659.html

Conley, H. (2018). China's Arctic Dream. Center for Strategic \& International Studies.

Doshi, R., A. Dale-Huang \& G. Zhang. (2021). Northern Expedition: China's Arctic Activities and Ambitions. Brookings Institution. https://www.brookings.edu/research/northern-expedition-chinas-arctic-activitiesand-ambitions/

Dvina29. (2016, 29. juli). Igor Orlov: «Belkomur» mozjet stat oporoj transportnogo karkasa Arktiki [Igor Orlov: Belkomur kan bli en pilar i transport-rammeverket i Arktis]. https://dvina29.ru/igor-orlov-belkomurmozhet-stat-oporoj-transportnogo-karkasa-arktiki/

DvinaInform. (2013, 22. april). Kitajtsy zainteresovalis stroitelstvom Arkhangelskogo glubokovodnogo morskogo porta [Kinesere er blitt interessert i å bygge Arkhangelsk dypvannshavn]. http://www. dvinainform.ru/politics/2013/04/22/13845.html

DvinaInform. (2016, 24. mai). Dmitrij Rogozin: Ne nado kormit sebja illjuzijami o dobrom djade Dmitrij Rogozin: Man bør ikke ha illusjoner om en snill onkel]. http://www.dvinainform.ru/archive/2016/05/24/ 42218.html

Dvinanews. (2015, 14. oktober). Igor Orlov: «Belkomur» - eto novyj Sjolkovyj put [Igor Orlov: «Belkomur er den nye Silkeveien»]. Pressemelding fra guvernøren og regjeringen i Arkhangelsk fylke. http://dvinanews. $\mathrm{ru} /-\mathrm{y} 37 \mathrm{dj} 7 \mathrm{r} 7$

Dvinanews. (2016, 11. august). Semen Vujmenkov: «Kitajskije partnjory podtverdili vysokuju stepen zainteresovannosti v realizatsii Belkomura» [Semjon Vujmenkov: «De kinesiske partnerne bekrefter høy grad av interesse for realisering av Belkomur»]. http://dvinanews.ru/-pvpkj89f

Dvinanews. (2017, 29. mars). Dmitrij Rogozin iVan Jan obsudili razvitije rossijsko-kitajskikh otnosjenij [Dmitrij Rogozin og Wang Yang diskuterte utviklingen av de russisk-kinesiske forbindelser]. Pressemelding fra guvernøren og regjeringen i Arkhangelsk fylke. http://dvinanews.ru/-v13rppjy

E24. (2018, 9. mars). Finland går videre med arktisk jernbane til Kirkenes: - En fantastisk dag. https://e24.no/ naeringsliv/i/kJvxGj/finland-gaar-videre-med-arktisk-jernbane-til-kirkenes-en-fantastisk-dag 
Felleserklæring. (2015, 8. mai). Sovmestnoje zajavlenije Rossijskoj Federatsii i Kitajskoj Narodnoj Respubliki ob uglublenii vseobemljusjtsjego partnerstva i strategitsjeskogo vzaimodejstvija i o prodvizjenii vzaimovygodnogo sotrudnitsjestva [Felles erklæring fra Den Russiske Føderasjon og Folkerepublikken Kina om fordypning av det altomfattende partnerskapet og strategisk samhandling og promotering av samarbeid av gjensidig nytte]. http://www.kremlin.ru/supplement/4969

Felleserklæring. (2018, 8. juni). Sovmestnoje zajavlenije Rossijskoj Federatsii i Kitajskoj Narodnoj Respubliki [Felleserklæring fra Den russiske føderasjon og Folkerepublikken Kina]). http://kremlin.ru/ supplement $/ 5312$

Føderasjonsrådet. (2017, 24. mai). V Sovete Federatsii v ramkakh «Tsjasa subekta Rossijskoj Federatsii» byla predstavlena Arkhangelskaja oblast [Innenfor rammen av "Det russiske føderasjonssubjekts time» ble Arkhangelsk fylke presentert i Føderasjonsrådet)]. http://council.gov.ru/events/news/80469

Gorokhova, A. \& V. Babaejva (2017, 22. desember). Belkomur: zjeleznaja doroga v nikuda [Belkomur: En jernbane til ingensteds]. Regnum. https://regnum.ru/news/economy/2361181.html

Glumskov, D. (2020, 25. Aug.). Primeta vremeni [Et tegn i tiden]. EkspertOnline Severo-Zapad. https://expertnw. com/from-editors/primeta-vremeni/?sphrase_id=10608

Gudev, P. A. (2019). Novyje riski i vozmozjnosti mezjgosudarstvennogo sotrudnitsjestva v Arktike [Nye risiki og muligheter ved interstatlig samarbeid i Arktis]. Arktika $i$ Sever, 36, 57-83. https://doi.org/10.17238/ issn2221-2698.2019.36.57

Henderson, J. \& A. Moe (2019). The Globalization of Russian Gas - Political and Commercial Catalysts. Edward Elgar.

Hsiung, W. C. (2016). China and Arctic energy: Drivers and limitations. The Polar fournal, 6(2), $243-258$.

Hsiung C. W. \& Røseth T. (2019). The Arctic dimension in Sino-Russian relations. I J. Bekkevold \& B. Lo B (red.) Sino-Russian relations in the 21st century. Palgrave Macmillan. https://doi.org/10.1007/978-3-31992516-5_8

Ivanov, I. S. (red.). (2018). Russian-Chinese dialogue: The 2018 model [RIAC rapport 39]. Russian International Affairs Council.

Izotov, I. (2013, 23 januar). «Belkomur» postrojat za pjatiletku [Belkomur kan bygges på fem år]. Rossijskaja gazeta. https://rg.ru/2013/01/23/reg-pfo/perm-belkomur.html

Jia, F. \& Bennett, M. M. (2018). Chinese infrastructure diplomacy in Russia: The geopolitics of project type, location, and scale, Eurasian Geography and Economics, 59(3-4), 340-377. https://doi.org/10.1080/ 15387216.2019.1571371

Jones, L. \& Zou, Y. (2017). Rethinking the role of state-owned enterprises in China's rise. Neww Political Economy, 22(6), 743-760. https://doi.org/10.1080/13563467.2017.1321625

Khusainov, F. I \& Ozjereljeva, M. V. (2019). Perevozki uglja i neftenalivnykh gruzov zjeleznodorozjnym transportom: tekusjtsjeje sostojanije i perspektivy [Freight of coal and liquid hydrocarbons by rail transport: Current condition and perspectives]. Transport Rossijskoj Federatsii, 4, 22-27.

Koivurova, T. \& Kopra, S. (2020). Chinese policy and presence in the Arctic. Brill Nijhoff.

Komiinform. (2015, 3. september). Rossia i Kitaj dogovorilis o sovmestnoj realizatsii projekta «Belkomur» [Russland og Kina har avtalt felles virkeliggjøring av Belkomur-prosjektet]. https://komiinform.ru/ news/126863/

KomiOnline. (2013, 27 juni). Kompanija Deutsche Bahn International GmbH podtverdila svoje utsjastije v projekte «Belkomur» [Selskapet Deutsche Bahn International GmbH har bekreftet sin deltagelse i Belkomur-prosjektet]. https://komionline.ru/news/41435

KomiOnline. (2015, 11 august). Kitajtsy i «Belkomur»: trekhletnjaja istorija zainteresovannosti [Kineserne og Belkomur: en treårig historie om interesse]. https://komionline.ru/node/69654

KomiOnline. (2016, 6. okt.). Kontsessionnoje soglasjenije s kitajskoj Poly Group po "Belkomuru» khotjat podpisat v natsjale 2017 goda [Man ønsker å undertegne konsesjonsavtale med kinesiske Poly Group for Belkomur i begynnelsen av 2017]. https://komionline.ru/node/74949

Kuratova, E. S. (2011). Zjeleznodorozjnaja magistral «Belkomur» - sukhoputnaja alternativa zapadnomu utsjastku Severnogo Morskogo Puti [Hovedbanen Belkomur - et landveis alternativ til det vestlige stykket av Den nordlige sjørute]. Transportnoe delo Rossii, 9, 88-90.

Luzyanin, S. G. \& Huasheng, Zh. et al. (2020). Russia-China dialogue: The 2020 model. [RIAC Rapport 58] Russian International Affairs Council. https://russiancouncil.ru/en/activity/publications/russia-chinadialogue-the-2020-model/

Leonov, S. (2019). Aktivizatsija politiki Kitaja v Arktike: predposylki, problemy, perspektivy [Aktivisering av Kinas politikk i Arktis: Bakgrunn, problemer, perspektiver]. Regionalistika, 6(5). https://doi.org/10.14530/ reg.2019.5.50 
Moe, A. (2020). A new Russian policy for the Northern sea route? State interests, key stakeholders and economic opportunities in changing times. The Polar fournal, 10(2), 209-227. https://doi.org/10.1080/ 2154896X.2020.1799611

Morokhin, S. (2017, 28. desember) V «mylnoj istorii» o «Belkomure» pojavilas neozjidannaja intriga [I såpeoperaen om Belkomur har det oppstått en uventet intrige]. Tribuna. http://www.tribuna.nad.ru/vmylnoj-istorii-o-belkomure-poyavilas-neozhidannaya-intriga/

Nilsen, T. (2017, 27. mars). Railway, port on agenda for China's Vice Premier in Arkhangelsk. Barents Observer. https://hebarentsobserver.com/en/industry-and-energy/2017/03/railway-port-agenda-chinas-vicepremier-arkhangelsk

Petrovskij, V. J. \& Filippovna, L. V. (2018). Strategija Kitaja po osvojeniju Arktiki i perspektivy rossijskokitajskogo sotrudnitsjestva $\mathrm{v}$ regione [Kinas strategi for å beherske Arktis og perspektiver for russiskkinesisk samarbeid i regionen]. I Y. Safronova (red.) Kitaj v mirovoj $i$ regionalnoj politike. Istorija $i$ sovremennost [Kina i verdens- og regionalpolitikk. Historie og samtid]. Institutt for studier av Fierne Østen, Det russiske vitenskapsakademi.

Pletnev, S. (2017, 30. mai). Belkomur nasjol investora [Belkomur har funnet en investor]. Gudok. https:// gudok.ru/newspaper/?ID $=1375080$

Pravda Severa. (2017a, 1. april). Igor Orlov ozvutsjil svoj vzgljad na itogi foruma «Arktika - territorija dialoga» [Igor Orlov uttrykte sitt syn på resulatene av forumet «Arktika - dialogens territorium»]. http:// pravdasevera.ru/politics/-gv8z0fwz

Pravda Severa. (2017b, 4. september).V Pekine predstavili projekty stroitelstva «Belkomura» i glubokovodnogo porta Arkhangelsk [I Beijing ble planene for bygging av Belkomur og dypvannshavn i Arkhangelsk presentert]. http://pravdasevera.ru/economics/-k9c34r0s

Pravda Severa. (2018, 31. mai). Kak v Sankt-Peterburge sozdavali ekonomiku doverija [Hvordan man i St. Petersburg skapte en tillits-økonomi]. https://pravdasevera.ru/2018/05/31/60b0a077b43ef52e7c669c1e. html

Pravda Severa. (2020a, 15. januar). Belkomur: perestsjitat tsifry [Belkomur: Se på tallene igjen]. http:// pravdasevera.ru/economics/-bvtsa $75 \mathrm{r}$

Pravda Severa. (2020b, 19. mai). Ekonomiku Severnogo morskogo puti podnimut mezjregionalnym projektom [Økonomien til Den nordlige sjørute vil bli løftet av et interregionalt prosjekt]. http://pravdasevera.ru/ economics/-rydxp4bh

Prezident Rossii. (2017a, 30 mars). Vladimir Putin prinjal utsjastije v plenarnom zasedanii IV Mezjdunarodnogo arktitsjeskogo foruma "Arktika - territorija dialoga» [Vladimir Putin deltok i plenumssesjonen til IV Internasjonale arktiske forum "Arktis - dialogens territorium»]. http://www.kremlin.ru/events/ president/news/54149

Prezident Rossii. (2017b, 15. september). Peretsjen porutsjenij po itogam sovesjtsjanija po voprosam razvitija transportnoj infrastruktury Severo-Zapada Rossii [Liste over instrukser etter konklusjonene fra møte om spørsmål knyttet til utvikling av trasnport-infrastrukturen Nordvest-Russland]. Pr-1881, p. 1. http:// kremlin.ru/acts/assignments/orders/55641

Prezident Rossii. (2020, 26. oktober). Strategija razvitija Arktitsjeskoj zony Rossijskoj Federatsii i obespetsjenija natsionalnoj bezopasnosti na period do 2035 goda [Strategi for utvikling av den russiske føderasjons arktiske sone og besørgning av nasjonal sikkerhet i perioden frem til 2035]. Dekret nr. 645. http://www. kremlin.ru/acts/news/64274

Redkije zemli. (2017, 26. mai).V stroitelstvo «Belkomura» investirujut kitajtsy [Kineserne investerer i byggingen av Belkomur]. http://rareearth.ru/ru/news/20170526/03196.html

Regjeringsordre. (2019, 21. desember). Plan razvitija infrastruktury Severnogo morskogo puti na period do 2035 goda [Plan for utbygging av infrastruktur for Den nordlige sjørute for perioden frem til 2035]. http://government.ru/docs/38714/

Regnum. (2020, 28. april). Belkomuru ne khvatajet gruzovoj bazy—vrio gubernatora Tsybulskij [Belkomur mangler fraktgrunnlag - fungerende guvernør Tsybulskij]. https://regnum.ru/news/polit/2932332.html

Rosmorport. (u.d.). Razvitije Arkhangelskim filialom obektov portovoj infrastruktury i flota a [Arkhangelskfilialens utvikling av havne-infrastruktur og -flåte]. Hentet 27. juli 2021 fra https://www.rosmorport.ru/ filials/arf_developmentofports/

Sazonov, S. (2020). Problemy i perspektivy infrastrukturnoj integratsii RF i KNR v ramkakh kontseptsii OPOP [Problemer og perspektiver for integrasjon av infrastruktur mellom Russland og Kina innenfor rammen av konseptet «én belte, én vei»]. I A. O. Vinogradov \& A. S. Isajev (red.), Rossia-Kitaj: sjansy $i$ vyzovy otnosjenij «novoj epokhi» [Russland - Kina: sjanser og utfordringer for forbindelsene i den «nye epoken»]. Moskva: Institutt for studier av Fjerne Østen, Det russiske vitenskapsakademi. 
Sjutsjalina, D., Vedenejeva, A. \& V. Sukhanov (2017, 18. des.). «Belkomur» predlagajut vsem zjelajusjtsjim [Belkomur tilbys til alle som ønsker]. Kommersant. https://www.kommersant.ru/doc/3500623

Tarakanov, M. A. (2014). Problemy, istorija i perspektivy transportnykh projektov v Arktike [Problemer, historien og perspektivene til transportprosjekter i Arktis]. Sever $i$ rynok, 6(43), 23-27. http://www.iep. kolasc.net.ru/journal/files/Sever-i-Rynok-2014-6.pdf\#page $=23$

Tass. (2013, 5. februar). Krupnejsjaja kitajskaja inzjenerno-stroitelnaja korporatsija vyrazila gotovnost investirovat v projekt "Belkomur» [Meget stort kinesisk engineering- og entreprenørselskap er rede til å investere i Belkomur-prosjektet]. https://tass.ru/arhiv/521733

Tass. (2017, 25. mai). Belkomur rail project brings new opportunities to Russia's Arctic regions. https://tass. com/economy/947651

Tass. (2020, 18. mai)). Belkomur dovedut do nenetskogo porta Indiga [Belkomur føres frem til havnen Indiga i Nenets]. https://tass.ru/ekonomika/8504183

Tass. (2021, 24. mars). Port Arkhangelska budet razvivatsia za stsjet strojek v Arktike i lesnykh gruzov [Arkhangelsk havn vil utvikles på grunnlag av utbyggingsprosjekter i Arktis og skogsprodukter]. https:// tass.ru/ekonomika/10986875

Transportministeriet. (2018. 15. februar). 15 fevralja v Sotsji Ministr transporta RF Maksim Sokolov prinjal utsjastije v rabote kruglogo stola "Infrastrukturnaja ipoteka: gosudarstvenno-tsjastnoje partnerstvo 2.0", prosjedsjego v ramkakh Rossijskogo investitsionnogo foruma [15. februar i Sotsji deltok Russlands transportminister Maksim Sokolov i arbeidet til rundebordet «Infrastruktur-lån: offentlig-privat partnerskap 2.0] Pressemelding fra Transportministeriet. https://mintrans.gov.ru/press-center/news/8553

Trunina, A. \& L. Podobedova. (2019, 10. april). Trutnev zajavil o neokupajemosti zjeleznodorozjnoj magistrali v Arktike [Trutnev erklærte ulønnsomhet for jernbanen i Arktis]. RBK. https://www.rbc.ru/economics/ 10/04/2019/5cadbefa9a794740f84eeab5

Tsygankova, S. (2016, 28. nov.). Zakhotelos Belogo - Kitajskije investory toropjatsia v Pomorje [Fikk lyst på Hvit [vin] - kinesiske investorer skynder seg til kystregionen]. Rossijskaja gazeta. https://rg.ru/2016/11/28/ reg-szfo/kitajskie-investory-profinansiruiut-stroitelstvo-arhangelskogo-porta.html

Vedenejeva, A. (2021, 27. januar). V Indigu plyvut tolko sroki [Til Indiga seiler bare tidsfristene]. Kommersant. https:/www.kommersant.ru/doc/4662563

Vedenejeva, A. \& A. Dzjumajlo. (2017, 10. mars). Kitajtsy osvaivajut berega Barentseva morja [Kineserne erobrer Barentshavets kyster]. Kommersant. https://www.kommersant.ru/doc/3237464

Vedenejeva, A. \& Zajnullin, J. (2020, 21. oktober). «Lavna» ne skladyvajetsia. Projekt ugolnogo porta vnov zabuksoval [Lavna tar ikke form. På nytt stopper planen for kullhavnen opp]. Kommersant. https://www. kommersant.ru/doc/4539838

Zubarev, D, (2020. 8 mars). Khusnullin objasnil resjenije otlozjit sozdanije VSM Moskva - Kazan [Khusnullin forklarte beslutningen om å utsette etableringen av høyhastighetsbanen Kazan-Moskva]. Vzglyad. https:// vz.ru/news/2020/3/8/1027778.html

Wu, W. (2018, 17. juni). How the Communist Party controls China's state-owned industrial titans, South China Morning Post. http://www.scmp.com/news/china/economy/article/2098755/how-communist-partycontrols-chinas-state-owned-industrial-titans 